\title{
Developing the Worksheet Books Integrating Character Building to Teach Budgeting Course
}

\author{
Benedecta Indah Nugraheni \\ Rita Eny Purwanti \\ Teacher Training and Education Faculty \\ Universitas Sanata Dharma \\ Yogyakarta, Indonesia \\ ben indah@usd.ac.id
}

\begin{abstract}
This research aimed to develop an educational product in a form of worksheet books integrating character building that was used as the appropriate media for learning Budgeting for students of Accounting Education Study Program, Faculty of Teacher Training and Education, Sanata Dharma University. The worksheet books were developed through a Research and Development. The procedure of the research adopted the steps of system approach to instructional learning program design by Dick and Carey. This research carried out nine steps of $R$ and $D$ starting from identifying instructional goals to formative evaluation. The formative evaluation was conducted in expert validation and trials. The subject of trials were the students of Accounting Education Study Program. The data was collected by the use of questioners and interviews, and analyzed descriptively. The result of this research showed that the worksheet books was appropriate to be used as a media for Budgeting course. This is showed by the result of the validation from: 1) the expert in materials; 2) the expert in character building; 3) the expert in instructional design; and 4) the expert of learning media. It is also showed by the result of one on one trials, small group trials, and field trials.
\end{abstract}

Keywords-developing, media, worksheet books, character building, budgeting

\section{INTRODUCTION}

Budgeting is one of courses that the curriculum of Accounting Education Study Program has. Budgeting is an important activity in business, in which planning and controlling system is conducted to carry out the managerial activities and responsibilities. Budgeting, which becomes the managerial tool to serve the planning and controlling functions, aims at obtaining the enterprise goal to satisfy customers and win in the competitions. Planning and controlling are two primary functions of management in business. Planning comprises the activities of setting the goals, developing company's thinking framework, selecting activities to obtain the goal, creating actions necessary to realize plans, evaluating and correcting actions to make new plans. Controlling is an activity to guarantee the efficient process toward the attainment of the predetermined goals. It comprises the identification of standards and objectives that will become reference for the intended achievements and correction for the any identified deviants.

The learning content of Budgeting course includes concepts of budgeting, such as definition and functions of budgeting in enterprise's managerial activities, relationship of budgeting and organization, and of income and production process. After the students have the understanding of budgeting concepts, the next materials to be learned are developing many kinds of budgeting, such as sale budget in which they learn forecasting techniques, making budgets of production, raw materials, direct labor costs, overhead costs, variable costs, receivable budget and cash, and capital.

Considering the content and characteristics of learning materials that need a lot of practices in Budgeting course, a variety of worksheets were definitely needed in our study program to facilitate the students to actively learn and implement their knowledge in making many kinds of budget. Working on worksheets, the students would more easily understand the procedure of budget making. Therefore such kind of worksheet was needed in a form of book that compiled a variety of budget making. This compilation of worksheets would become a worksheet book that would contribute to the students' understanding of the relationship of budgets in an enterprise. Cases that the book adopts were develop to build comprehensive understanding of budgeting. In other context, worksheets can also show the interrelationship between one component and the others [1].

There were some reasons for the development of worksheet books in the learning process. Using worksheets will help the students proactively construct knowledge and have a scaffolding effect which helps learners construct knowledge and maintain attention. Worksheet is also seen as a way to keep learners focused on task completion during activities. [2][3].Worksheets are also important for increasing the efficiency in learning environment [3][4].

Conceptual learning require the use of well designed equipments and material such as worksheets, that can be simplify the concepts for students to construct in their minds [3]. Johnson states that completing concept worksheet has many benefits and advantages, e.i. students have the opportunity to identify and analyze important concepts and think about the meaning of these concepts by integrating visual 
and verbal understanding; the concept worksheet gives the teacher an easy way to identify student's misconceptions and misunderstandings; it gives students an efficient tool for reviewing material before the final examination; and the process of writing about the concept increases the students' ability to think critically and organize their thoughts. [5]

The result of an experiment suggested that worksheet can produce increased learning. Since the worksheet gives both reading and writing experiences in a concise form, it helps to make the learning more nearly permanent [6][7].

In most of courses, learning is commonly dominated by development of cognitive and psychomotor aspects, and less pays attention to affective one. Learning commonly gives less attention to learning values that can develop attitudes important for the students to have and for their life. In the meantime, teachers often see that there is a tendency that the young generation do not have good attitude and behaviors [8]. The negative behaviors that the students often show are dishonesty in doing the examination, carelessness in doing learning tasks, lack of independence and responsibility in doing assignments, low endurance, etc. That is why character education in every process of learning is undoubtedly necessary. Many arguments say that character building is more effective when it is conducted by teachers at schools [8][9]. Character education programs are intentional efforts by schools and teachers to foster good character in students and to help them "acquire a moral compass - that is a sense of right and wrong and the enduring habits necessary to live a good life [10].

Character education can not be isolated as a separated discipline [11]. A research showed that there was a positive correlation between character education and academic achievement [12]. In this research, the developed worksheet books integrated character building contents, in addition to variety of budgeting learning contents. Working on the worksheet books that integrated character building, students would be guided to acknowledge, believe, integrate, and appreciate good values that would build their character.

A number of values that were considered relevant with the learning process of budgeting and expected to be learned and practiced in the learning process were carefulness, honesty, responsibility, and autonomy. Therefore, it is hoped that these practical worksheet books of budgeting would facilitate learning all aspects of the students, not only the cognitive and psychomotor aspects, but also affective aspect to develop the whole students' personality.

There were also several considerations in developing the practical worksheet books: 1) The Accounting Education Study Program of Sanata Dharma University lacked practical, proper books that facilitated learning budgeting; 2) From the aspect of content, the existing worksheet book did not have sufficient content coverage for the whole semester; and 3) The existing practical books had not integrated character education. Those facts encouraged us to develop these worksheet books of budgeting that integrated character education to be implemented in Budgeting course for the $5^{\text {th }}$ semester students of Accounting Study Program at Sanata Dharma University.
As the aforementioned, that one of the objectives this worksheet book development was to help students understand the relationship of various budgets. This objective can actually be facilitated by computer software [13]. However, this kind of software is unfortunately not available in Indonesia.

Working on the developed worksheet books, students learn budgeting manually. On one side this shows weaknesses. On the other side, this brings about benefits for the students. For example, students experience real process of budgeting that contribute to deeper understanding. Besides, these worksheet books can carry out education of values as the process of character education.

This research had one major research question that was formulated as: "What is the design of worksheet books integrating character building that is suitable for learning Budgeting for the students of Accounting Education Study Program?"

In specific, this question was broken down into several questions, namely:

1. What is the quality of the worksheet books in the aspect of materials/content?

2. What is the quality of the worksheet books in the aspect of character building contents?

3. What is the quality of the worksheet books in the aspect of instructional design?

4. What is the quality of the worksheet books in the aspect of media (face validity)?

\section{METHOD}

This research utilized Research and Development as the research method. Research and Development is a process of developing education products that are effective for education and learning [14]. Research and Development is an attempt to develop an effective product in a form of learning materials, media, activities, to be implemented in learning instead of theoretical testing [15].

The research procedure adopted the steps of instructional program design suggested by Dick and Carey, that consisted of 10 steps, namely, (1) assess needs to identify goal (s), (2) conduct instructional analysis, (3) analyze learners and contexts, (4) write performance objectives, (5) develop assessment instruments, (6) develop instructional strategies, (7) develop and select instructional materials, (8) design and conduct formative evaluation of instruction, (9) Revise instructions, (10) design and conduct summative evaluation [14].

The step of formative evaluation was conducted in expert validations and product trials. The expert validation was conducted by experts in materials, media, and character education. Then, the product was implemented in several trials, namely, one on one trial, small group trial, and field trial. The research subjects were the fifth semester students of Accounting Education Study Program of Sanata Dharma 
University. The numbers of the students were 4 students in one on one trial, 8 students in small group trial, and 107 students in the bigger group of field trial.

The data were collected by the use of questioners and interviews. The data were quantitative and qualitative in nature. The quantitative data were resulted from the assessment of the worksheets book. The qualitative data were in a form of the suggestions or comments that were intended to improve the designed product. Both of data were analyzed descriptively. The result of product evaluation data analysis is converted from quantitative to qualitative data. Normal curve was used as the reference within 5 scales, as presented in Table 1.

TABLE I. DATA CONVERSION FROM QUANTITATIVE TO QUALITATIVE

\begin{tabular}{|c|c|}
\hline Interval Score & Criteria \\
\hline $\mathrm{X}>4.21$ & Very good \\
\hline $3.40<\mathrm{X} \leq 4.21$ & Good \\
\hline $2.60<\mathrm{X} \leq 3.40$ & Sufficient \\
\hline $1.79<\mathrm{X} \leq 2.60$ & Less than sufficient \\
\hline $\mathrm{X} \leq 1.79$ & Insufficient \\
\hline
\end{tabular}

\section{RESULT AND DISCUSSION}

After several steps of development were conducted the product in a form of worksheet books was developed. The worksheets book consist of two books, as follows:

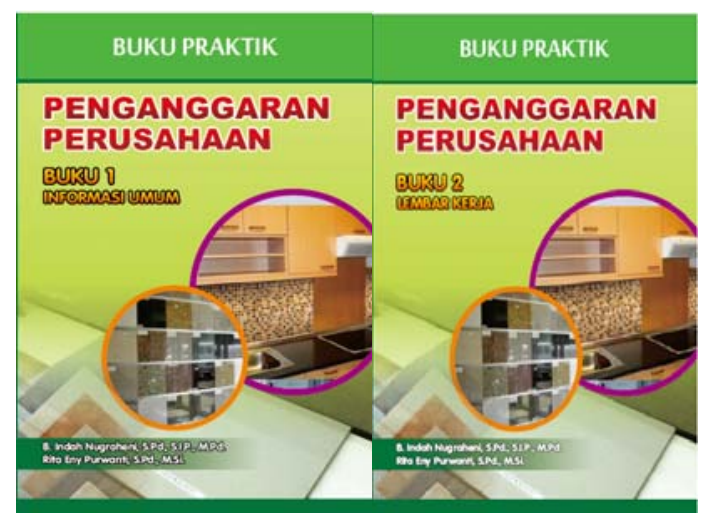

Figure 1. Book 1 and Book 2 of worksheets books.

Book 1 entitled general information. At the beginning, it is displayed the learning outcome of budgeting course. Next pages contained the description of a hypothetical manufacturing company, i.e. the product, data of sales, the pattern of sales, product inventory, production process, departementation, and activity base. The instructions to complete the case is presented at the end of this book.

Book 2 is contained the worksheets, character building content, and reflection sheets. Worksheets in a form of tables to make many kinds of budget. Character building content is available in every chapter and placed after worksheets. It is contained an inspirational stories and a reading to deliver reflection, that has to read by the students before they carry out reflection. After that, they are asked to write down the result of reflection at the reflection sheets based on the guiding questions. At certain pages, it is added some quotes related to honesty, carefulness, responsibility, and independence values, as seen at figure 4. At the end of Book 2, it is provided the instrument to asses students attitude and also the rubric of evaluation.

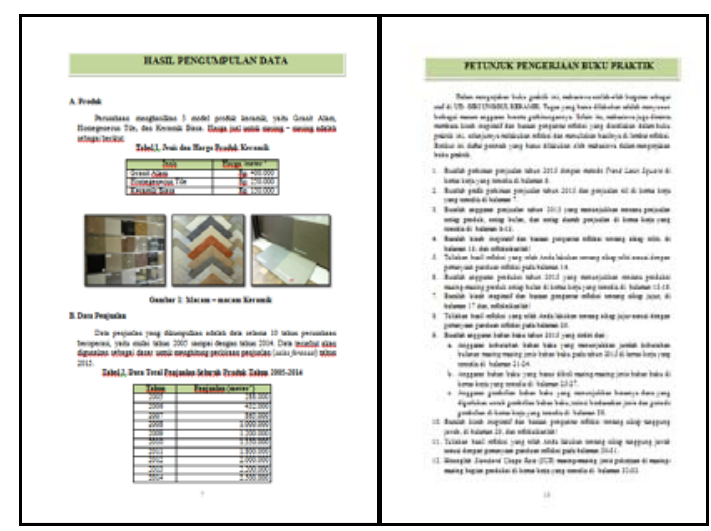

Figure 2. Sample of data and instruction in Book 1.

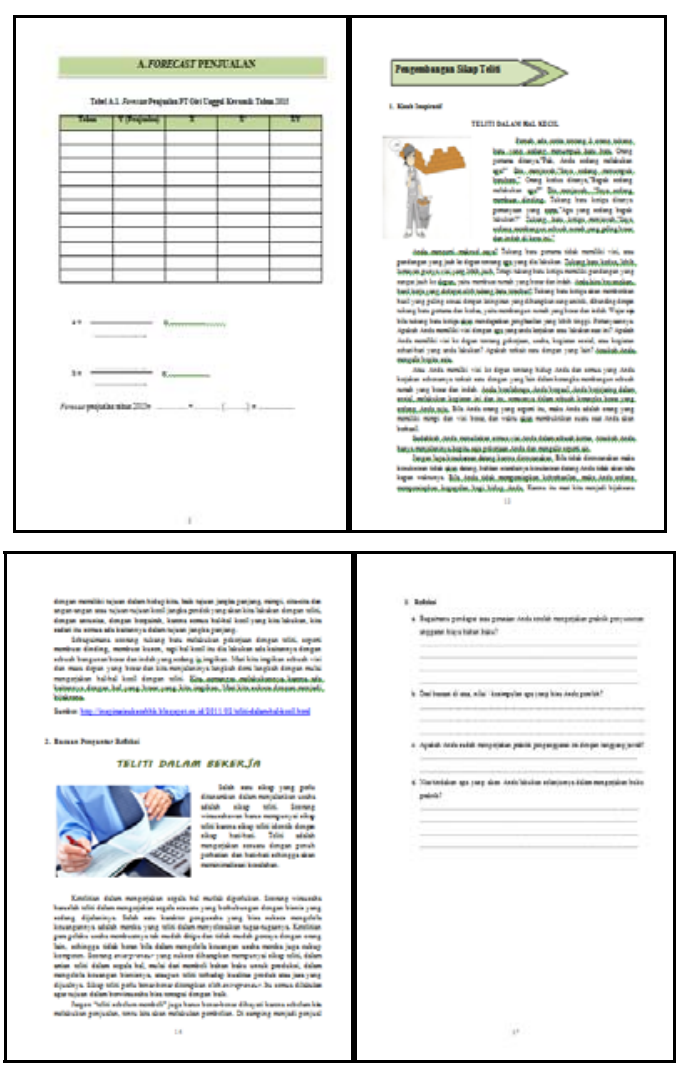

Figure 3. Sample of worksheets, character building materials, and reflection sheets in Book 2. 


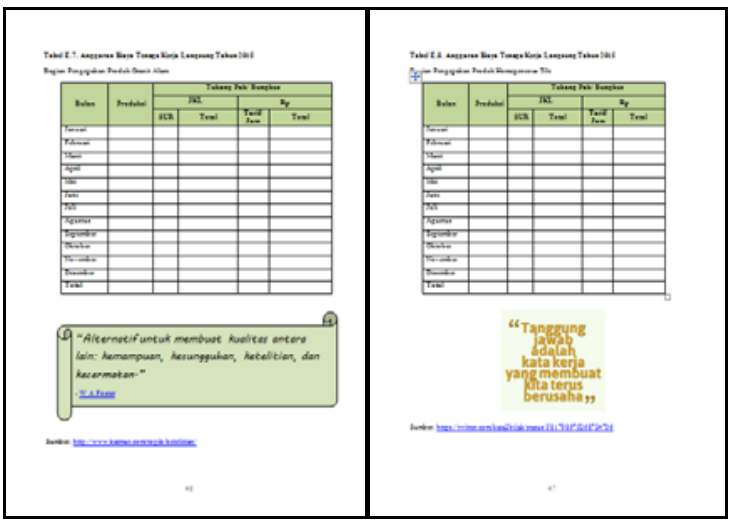

Figure 4. Some quotes added at certain pages.

After the product proto-type was developed, expert validations and product trials were conducted. The qualitative data in a form of comments and feedback were then used to revise the product. The revision was conducted in the aspects of contents, instructions, face validity, worksheets, and the content of character building materials. The quantitative data of expert validations were analyzed using descriptive statistics. The result of analysis is presented in Table II, as follows.

TABLE II. RESULT OF EXPERT VALIDATION

\begin{tabular}{|l|l|c|c|}
\hline \multirow{2}{*}{ Kinds of Trials } & \multicolumn{3}{|c|}{ Evaluated Aspects and Result } \\
\cline { 2 - 4 } & \multicolumn{1}{|c|}{ Evaluated Aspects } & $\begin{array}{c}\text { Average } \\
\text { Scores }\end{array}$ & Categories \\
\hline $\begin{array}{l}\text { Expert in material } \\
\text { development }\end{array}$ & Content (13 items) & 4.07 & Good \\
\hline $\begin{array}{l}\text { Expert in character } \\
\text { education }\end{array}$ & $\begin{array}{l}\text { Character building } \\
\text { content (10 items) }\end{array}$ & 3.80 & Good \\
\hline $\begin{array}{l}\text { Expert in } \\
\text { instructional design }\end{array}$ & Instructional (15 items) & 4.60 & $\begin{array}{c}\text { Very } \\
\text { Good }\end{array}$ \\
\hline $\begin{array}{l}\text { Expert in learning } \\
\text { media }\end{array}$ & Face validity (10 items) & 3.70 & Good \\
\hline
\end{tabular}

a. Sample of a Table footnote. (Table footnote)

The product evaluation of the contents aspects from the expert in material development showed that the average score was 4.07 having the category of "good". The aspect of character building was evaluated and determined as "good" by the expert in character education with the average score of 3.80. Expert in instructional design evaluating the instructional aspect gave the category of "very good". Finally, the result of evaluation conducted by the expert in learning about the face validity showed that the average score was 3.70 belong tothe category of "good".

Based on the result of product evaluation from all the validators and their feedback, the product of worksheet books were revised. The next step after the product revision was the product trials.
TABLE III. RESUlt OF PRODUCt TRIALS

\begin{tabular}{|c|c|c|c|}
\hline \multirow{2}{*}{$\begin{array}{c}\text { Kinds } \\
\text { of } \\
\text { Trials }\end{array}$} & \multicolumn{3}{|c|}{ Evaluated Aspects and Result } \\
\hline & Evaluated Aspects & $\begin{array}{c}\text { Average } \\
\text { score }\end{array}$ & Categories \\
\hline \multirow{4}{*}{$\begin{array}{l}\text { One on } \\
\text { one }\end{array}$} & Content (13 items) & 4.15 & Good \\
\hline & Instructional (15 items) & 3.88 & Good \\
\hline & Face validity (10 items) & 4.68 & Very good \\
\hline & Total average score & 4.18 & Good \\
\hline \multirow{4}{*}{$\begin{array}{l}\text { Small } \\
\text { Group }\end{array}$} & Content (13 items) & 4.32 & Very good \\
\hline & Instructional (15 items) & 4.33 & Very good \\
\hline & Face validity (10 items) & 4.45 & Very good \\
\hline & Total average score & 4.36 & Very good \\
\hline \multirow{4}{*}{ Field } & Content (13 items) & 4.01 & Good \\
\hline & Instructional (15 items) & 4.01 & Good \\
\hline & Face validity ( 10 items $)$ & 4.07 & Good \\
\hline & Total average score & 4.03 & Good \\
\hline
\end{tabular}

In one on one trial, two aspects, i.e., content and instructional resulted in "good" category, while the face validity aspect belonged to "very good" category. The total average score was 4.18 showing the "good" category. In small group trial, three aspects were given "very good", categories. The total average score was 4.36 belonging to the "very good" category. Finally, in the field trial, all aspects belonged to "good" categories. As overall, from this trial the product was categorized as "good" as it showed the total average score of 4.03 .

\section{CONCLUSION}

This research and development has developed an educational product in a form of worksheets book integrating character education for budgeting learning. The result showed that this product has been valid to be used as learning media for students of Accounting Education Study Program, Faculty of Teacher Training and Education, Sanata Dharma University. These worksheets book has been considered valid after the result of both product validation and trials showed the overall average scores showed categories of "good" and "very good". Besides, during the process of development this product was revised based on the feedback from the validators who were experts in their fields and the students.

This research has conducted nine of ten steps of Research and Development. The last step, i.e., design and conduct summative evaluation, would be the next suggested research. This step is meant to conduct the effectiveness of the product to increase the students' understanding of the material and develop the students' characters. 


\section{V.ACKNOWLEDGMENT}

We would like to thank the Research and Community Service Institute of Sanata Dharma University for funding this research.

\section{REFERENCES}

[1] H. Mann, "A worksheet for demonstrating the articulation of financial statements," The Accounting Review, vol. 59, no. 4, pp.669-673, October 1984 .

[2] J.C-Y Sun and K-H. Lee, "Which teaching strategy is better for enhancing anti-phishing learning motivation and achievement? The concept maps on tablet PCs or worksheets?," Journal of Education Technology \& Society, vol. 19, no. 4, pp. 87-99, October 2016.

[3] Z.B. Kibar and A. Ayas, "Developing a worksheet about physical and chemical event," Procedia Social and Behavioral Sciences 2 (2010), pp. 739-743.

[4] A.R.H. Pincus, "What's a teacher to do? Navigating the worksheet curriculum," The Reading Teacher, vol. 59, no. 1, pp. 75-80, September 2005

[5] C. Toumasis, "Concept worksheet: An important tool for learning," The Mathematics Journal, vol. 88, no. 2, pp. 98-100, February1995.

[6] A.B. Roberts and G. Parchert, "Do worksheets improve film utilization?," Audio Visual Communication Review, vol. 10, no. 2, pp. 106-109.

[7] F. Karsli and C. Sahin, "Developing worksheet based on science process skills: factors affecting solubility," Asia-Pasific Forum on Science Learning and Teaching, vol. 10, issue 1, article 15, p.1, June 2009.

[8] A. Agboola and K.C. Tzai, "Bring character education into classroom," European Journal of Educational Research, vol. 1, no. 2, pp. 163-170, 2012.

[9] A.M. Chapman, "Implementing character education into school curriculum,” ESSAI, vol. 9, article 11, 2011.

[10] M.H. Romanowski, "Through the eyes of students: high school students' perspective on character education," American Secondary Education 32 (1) Fall 2003, pp. 3-20.

[11] J. Gilnes, "Classroom Practice. How to integrate character education into the curriculum," Phi Delta Kappan, vol. 85, no. 3, pp. 243-245, November 2003.

[12] J.S. Benninga, M.W. Berkowits, P. Kuehn, and K. Smith, "The relationship of character education implmentation and academic achievement in elementary school," Journal of Research on Character Education, vol. 1, no. 1, pp. 19-32, 2003.

[13] J.T. Sale, "Using computerized budget simulation models as a teaching device," The Accounting Review", vol. 47, no. 4, pp. 836-839, October 1972.

[14] W. Borg and M.D. Gall, "Educational Research: An Introduction," New York: Longman, 2003, pp.570-571.

[15] L.R. Gay, "Educational Research: Competencies Analysis and Application( $3^{\text {rd }}$ ed.)," Singapore: Macmillan Publishing Company, pp.1. 